\title{
Identity Construction via Social Hybridity: A Metatextual Analysis of Two Novels
}

\author{
ALI BADEEN MOHAMMED AL-RIKABY \\ College of Arts \\ Mustansiriyah University \\ alibadeen1972@gmail.com \\ SIHAM HATTAB HAMDAN \\ College of Arts \\ Mustansiriyah University \\ sihamhattab2017@gmail.com \\ TENGKU SEPORA TENGKU MAHADI \\ School of Languages, Literacies and Translation \\ Universiti Sains Malaysia \\ tsepora@usm.my \\ DEBBITA TAN AI LIN (CORRESPONDING AUTHOR) \\ School of Languages, Literacies and Translation \\ Universiti Sains Malaysia \\ debbitatan@usm.my \\ SHAIDATUL AKMA ADI KASUMA \\ School of Languages, Literacies and Translation \\ Universiti Sains Malaysia Penang \\ shaidatul@usm.my
}

This work is licensed under the terms of the Creative Commons Attribution (CC BY) (https://creativecommons.org/licenses/by/4.0/). 


\begin{abstract}
Mixed-identity individuals often encounter many problems on questions of their identity, belonging, and other forms of multiracialism. A mixed-identity individual is often seen as a lonely or isolated individual. Two well-known novels focus on this dimension - D. Defoe's The Fortunes and Misfortunes of the Famous Moll Flanders (1996) and C. Rajendra's No Bed of Roses: The Rose Chan Story (2013). The two authors' emphasized portrayal of their heroines' problematized hybrid identities and resultant complex struggles are the focal points of this study. The broad aim was to analyze the explicit and implicit metatextualities of such identities (via social hybridity) in these texts, within the scope of constructing an identity in terms of (dis)inclination towards multiracial marriages. The study is grounded in Genette's $(1997,1992)$ theory of intertextuality; with respect to explicit metatextuality, the researchers focused on the strategies of interpretation and negation, whereas ironies and parodies were tackled as implicit metatextuality. Intertextuality is an integral part of textology and textual analysis of both literary and non-literary works. It is a framework to study text constructions and internal relations between texts as well as interactions between authors and readers. On the whole, the results demonstrate that irrespective of the novelists' backgrounds (Defoe being English and Rajendra a Malaysian) as well as the novels' settings (Moll's story was set in London, UK, while Rose's was set in Penang, Malaysia), there are clear instances of the shaping of (dis)inclination for hybrid marriages and their resultant identities, with Rajendra's work exhibiting more of such identities than Defoe's. This study and its findings are of significance to scholars engaged in literary research, and might potentially facilitate students' understanding of Western and Eastern comparative literature in terms of identity construction and mutual communication in diverse societies.
\end{abstract}

Keywords: $\quad$ identity construction; intertextuality; metatextuality; Moll Flanders; Rose Chan

It is to be noted that the findings presented in this paper are largely qualitative properties. The views and interpretations expressed are those of the researchers (unless stated otherwise), and do not serve as estimations of the novels' quality in any way.

Published online: April 2021

To cite this article: Mohammed Al-Rikaby, A. B., Hamdam, S. H., Mahadi, T. S. T., Tan, D. A. L., Kasuma, S. A. A. (2021). Identity Construction via Social Hybridity: A Metatextual Analysis of Two Novels. International Journal of Language, Literacy and Translation 4(1), 12-27. https://doi.org/10.36777/ijollt2021.4.1.040

To link to this article: https://doi.org/10.36777/ijollt2021.4.1.040 


\section{INTRODUCTION}

The macro topic of 'social hybridity in marriages' is the crux of two well-known literary texts Daniel Defoe's The Fortunes and Misfortunes of the Famous Moll Flanders and Cecil Rajendra's No Bed of Roses: The Rose Chan Story. Defoe and Rajendra have constructed various episodes relating to the complexities of such marriages in their work, often within the frame of the heroines' respective identity-formation journeys. The primary elements focused on herein are culture shock and religious practices. For instance, the heroines' difficulties in adapting to new cultures and societal norms, as well as the challenges Rose Chan (a non-Muslim prior to marriage) faced when she was married to a Muslim man. Both heroines, however, failed to cope and left many children behind to be looked after by others as they moved from one city to another, and from one craft to another.\#

All these problems are operationalized alongside the foundation of the macro topic of social hybridity (within the context of marriages). In this paper, the stories are treated as metatexts of how the two authors, one English and the other Malaysian, viewed and portrayed the social and/or cultural problems inherent in or related to such marriages.

\section{RESEARCH PROBLEM AND AIM}

The quest for identity and issues related to social hybridization are recurrent themes and objects of investigation in fiction. In their literary work, Defoe and Rajendra demonstrate that multiracial marriages can represent an essential element of the blending of different cultures for the construction of a hybrid society. However, the different literary experience offered by each of the two authors calls for a fresh debate on the issue of constructing identities via cultural hybridization.

Also, in both texts, social hybridization (or hybrid socialization) plays an integral part in the narrative textology. Therefore, an intertextual analysis of both literary works is needed as a framework to study the textual constructions and the internal relations between these texts, as well as the possible interactions between culturally different authors. Because of the overall growth in studies concerning intertextuality, cognizance of text constructions and textual relations should be deemed a research priority to extend the current knowledge base in extant literature.

In addition, literary texts like Defoe's Moll Flanders and Rajendra's Rose Chan are very engaging and meaningful to study as they are based on the veins and workings of society, and are rich sources that permit us to continue contributing to the rich, multifaceted field of textology. Also, there is no published literary study to date that focuses on metatextuality cognizance, in the reading of a Western text and an Eastern one, both interwoven by the thread of an identity search via social hybridity.

In essence, the present study aimed to analyze both the explicit and implicit metatextual elements in the mentioned texts, within the scope of '(dis)inclination' in terms of (dis)inclination towards constructing an identity via social hybridity (within the context of multiracial marriages). 


\section{RELATED LITERATURE}

\section{HYBRIDITY}

Hybridity is a familiar notion in various disciplines, most notably within the social sciences. Stark inequalities arising from hegemony and colonialism, variegated power relations, transculturation and multiculturalism, ambivalent identities, and interweaving scholarship are among the elements - exigencies even - that have allowed the notion of hybridity to manifest in diverse areas. At its basest, hybridity refers to mixture, or a blend - resulting in new dimensions and elaborations. According to García-Canclini (2001), hybridity "has been used by authors in the social sciences, literary, artistic, and cultural studies to designate processes in which discrete social practices or structures, that existed in separate ways, combine to generate new structures, objects, and practices in which the preceding elements mix." (p. 7095)

Hybridity is fundamentally a concept that cannot be set apart from social realities, encapsulated within a framework that embraces fusion and, for lack of a better term, inbetweenness. It has been viewed differently; from the lens of translation, it is sometimes seen as a pejorative quality, an undesirable interference observable in translated works (Mollanazar \& Parham, 2009), and from the lens of consciousness, the hybrid stance affords us the possibility for an enlightened and critical worldview (Marotta, 2008).

Regardless, hybridity has been an area of investigation for some time, primarily within the context of discourses about postcolonialism, globalisation, popular culture, and diasporas. Within the bounds of linguistics and the literary realm, hybridity has been applied and articulated in research concerning 'mixed' and 'revived' languages, as well as in research on literary translations. There is, however, a paucity in terms of the study of hybridity within the more specific context of identity construction via social hybridity, focusing on (dis)inclination towards hybrid (or multiracial) unions. A search of the canon of existing scholarship reveals both the novelty and the pertinence of the present study, and of its relevance to educators and scholars engaged in studies on hybridity and identity construction.

\section{INTERTEXTUALITY AND METATEXTUALITY}

Intertextuality fundamentally means that there is no isolated text and that every new text is a manifestation of an old one (Halliday, 2003; Abrams, 1993). To put it simply, every new text results from a set of extant textual relations and these relations can be filtered via a later text. In theorizing intertextuality, Kristeva (1986, p. 37) states that "any text is constructed as a mosaic of quotations; every text is the absorption and transformation of another". Therefore, reading and analyzing any text depends very much on being cognizant of other interacting texts since the textual elements of the old text (in)advertently influence the new one.

Allen (2000) contends that because of intertextuality and the realization of such intertextual elements, the author can create and present a new text and the reader's awareness should enable him/her to discover the (new) meanings within it. In other words, the author, in producing the new text, (un)consciously interacts with a network of codes, references, themes, topics, structures and other features of related texts. Therefore, these intertextual elements live, move and exist in the new text in the form of indications, adaptations, quotations, allusions, parodies, ironies, hybridizations and implications. 
Bloor and Bloor (2007) opine that although intertextuality is a major aspect of all text types whether these texts are journalistic, scientific, philosophical, historical or religious in nature most studies on intertextuality and textual analysis have concentrated on literary texts because of the character of such texts, which are often saturated with elements like culture-specific expressions, implications and recreations. They also believe that these elements play a vital role in the reading process.

Motivated by Bakhtin's The Dialogic Imagination (1981), Kristeva maintain that "every text is an absorption and transformation of another" (p. 66). To Kristeva, all signifying texts are the result of the transformation of former signifying systems. As such, no text is original or is made by itself in isolation from other texts. Essentially, Kristeva's fundamental position here is that all texts are influenced by other texts, or by other related textual elements.

Barthes (1974) proposes that intertextual elements are not transferred objectively from the writer to the reader of the text, but are realized through five distinct codes. These codes are "the proairetic code" (p. 19) which refers to the reader's principle of suspense or anticipation; the "hermeneutic code" (p. 19) which signifies any element in the story that is enigmatic for the readers; the "semic code" (p. 20) which indicates any element in a work of fiction that suggests an additional meaning by way of connotation; the "symbolic code" (p. 20) which denotes a deeper principle that organizes meanings by way of mediation; and the "referential code" (p. 20) which points to a reader's shared knowledge about the way the world works.

Genette (1997, 1992) perceives all textual relations as transtextuality, categorizing these relations into five main types: intertextuality, architextuality, paratextuality, metatextuality and hypertextuality. Additionally, intertextuality is specifically split into two sets: explicit and implicit. The former refers to direct quotations, interpretations and negations whereas the latter refers to plagiarism, allusions, parodies and ironies.

Genette (ibid.) essentially expanded Kristeva's and Barthes's notions and principles of intertextuality. He added the modes of hypotextuality and metatextuality. For him, metatextuality focuses on both the explicit and implicit critical commentaries of one text on another text. Hypotextuality, meanwhile, highlights the relationship between a text and a preceding 'hypotext' text on which it is based but which it transforms, modifies, elaborates or extends (including parody or translation). Utilizing Genette's theory, this study explores the modes of metatextuality that the two writers extend to their characters' lives and actions, and the representation of social hybridity codes via mechanisms such as quotation, commentary, parody, allusion, imitation, and ironic transformation.

Halliday (2003) considers intertextuality as the history of a text. Such history shows itself in the cyclical chain of past texts which are connected to and have influences on the present text. He also believes that no text is made without intertextual elements. He asserts that each text is a combination of intertextual cycles which make the history of that text. Therefore, it can be claimed that every literary text is the product of two levels: metatextuality and the author's creativity. Metatextuality, in essence, is the attachment of relating texts to the intended text via means like adaptation, quotation, irony, parody, negation, implication, allusion, and recreation. In opposition to Halliday, Widdowson (2004) views intertextuality as a linguistic notion. He suggests Halliday's model to be insufficient, but confirms that intertextuality is indeed substantial and vital in literary analysis. 
Meanwhile, Fairclough (2003) is of the opinion that a text is a combination of a number of intertextual elements such as functional, lexical, grammatical, coherence, and textual structures. When analyzing a text, these should be considered in depth. He emphasizes also the vitality of intertextuality in text construction and reconstruction. For Fairclough, intertextuality is the reconstruction of the chain of texts or network of texts in the new text.

\section{ANALYTICAL FRAMEWORK}

Gerard Genette's (1992) model of metatextuality demonstrates that "all literary text critics, for centuries, have been producing metatext without knowing it" (p. 82). The texts utilized in the present study were treated as metatexts from two perspectives: English and Malaysian. The novels reflect what their authors may have perceived as an important social issue - hybrid marriages and the children left behind.

To frame an analysis for the two novels, the researchers elected to rely on the modes of metatextuality categorized by Genette $(1997,1992)$ to examine the strategies of interpretation and negation as explicit elements, and ironies and parodies as implicit elements. These rhetorical elements were analyzed in terms of macro and micro dimensions.

\section{METHODOLOGY}

\section{CORPUS AND PROCEDURES}

Genette's $(1997,1992)$ model of metatextuality analysis was employed as the taxonomy for this descriptive-comparative study, and the corpus comprised Text 1: Defoe's The Fortunes and Misfortunes of the Famous Moll Flanders (1996 publication) and Text 2: Rajendra's No Bed of Roses: The Rose Chan Story (2013).

As the novels represent portraits of the macro topic and offer abundant examples of explicit and implicit elements, they form a fertile corpus for this study. The analysis procedures are as follows:

(1) Synopsis (macro themes in both novels)

(2) Macro-intertextuality (frequencies of explicit metatextual elements in both novels)

(3) Micro-intertextuality (frequencies of implicit metatextual elements in both novels) 
IJoLLT Vol. 4, No. 1 (March) 2021

eISSN: 2637-0484

The structure of the study is as follows:

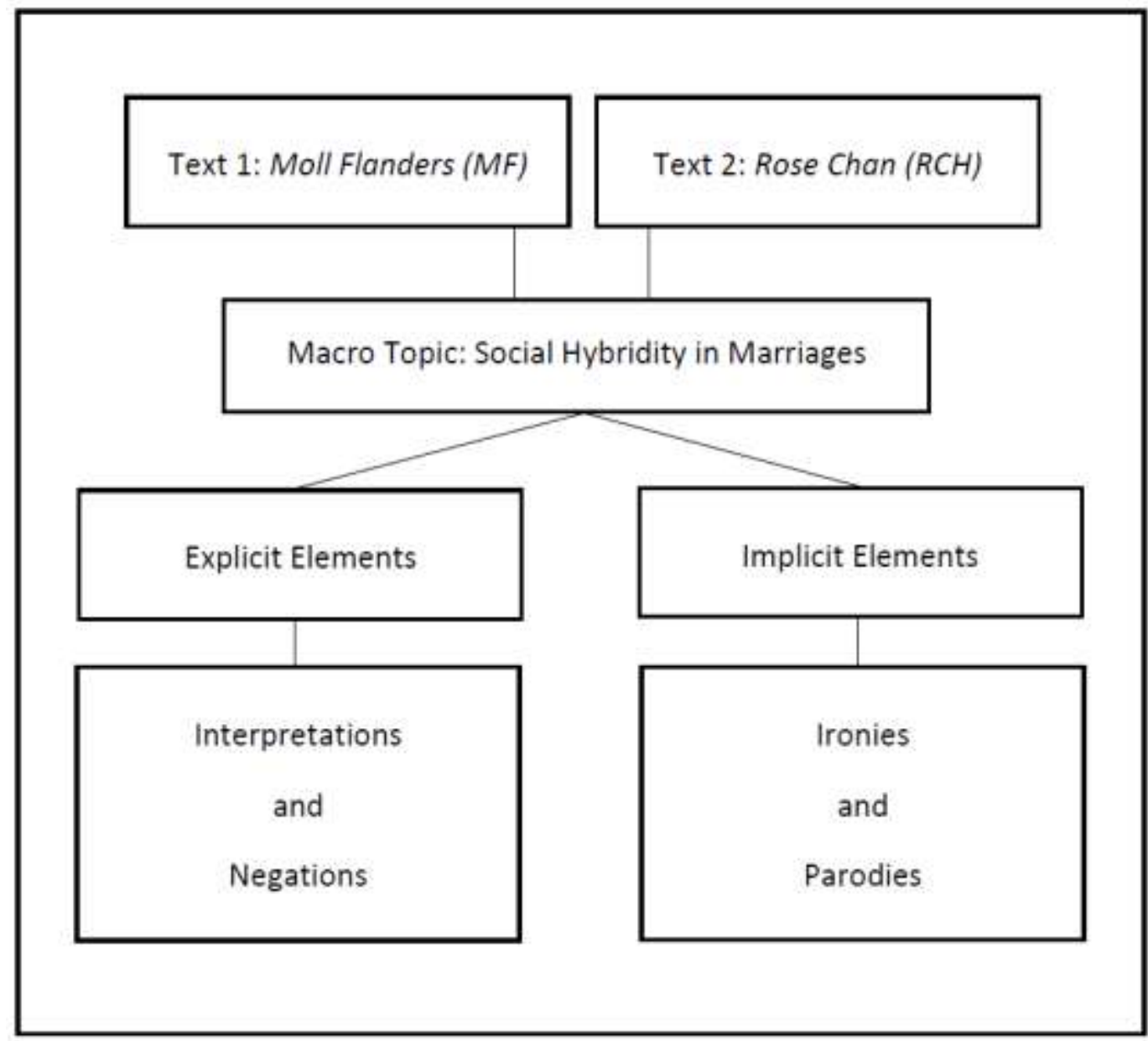

Figure 1: Structure of the present study

ELEMENTARY STATISTICS PRIOR TO FULL ANALYSIS

Table 1

Text 1: Defoe's The Fortunes and Misfortunes of the Famous Moll Flanders

\begin{tabular}{llll}
\hline Author's Nationality & English & Number of Marriages & At least five \\
\hline Story's Main Setting & $\begin{array}{l}\text { London, } \\
\text { United Kingdom }\end{array}$ & $\begin{array}{l}\text { Success/Failure of } \\
\text { Attempts }\end{array}$ & Largely failed \\
\hline Heroine & Moll Flanders & Children & At least five \\
\hline
\end{tabular}

Table 2

Text 2: Rajendra's No Bed of Roses: The Rose Chan Story

\begin{tabular}{llll}
\hline Author's Nationality & Malaysian & Number of Marriages & Five \\
\hline Story's Main Setting & Penang, & $\begin{array}{l}\text { Success/Failure of } \\
\text { Attempts }\end{array}$ & Largely failed \\
\hline
\end{tabular}




\begin{tabular}{llll}
\hline Heroine & Rose Chan & Children & At least five \\
\hline
\end{tabular}

Tables 1 and 2 present the elementary statistics pertaining to the study's corpus, providing a clear overview of the essence of each text as well as their general comparability, particularly in terms of number of marriages, success/failure of attempts, and number of children produced from the unions.

\section{FINDINGS AND DISCUSSION}

TEXT 1: DEFOE’S THE FORTUNES AND MISFORTUNES OF THE FAMOUS MOLL FLANDERS

\section{Synopsis (Macro Themes)}

At the end of his production of The Fortunes and Misfortunes of Moll Flanders, Lascelles (1996) stated the following: "in 18th century London a woman survives by whoring and thieving, determined to gain - by any means - a secure place in her society". If this hypothetical view is objective, it can help us decide on a general construct regarding the features of hybrid marriages in that era. Little (2002) opines that negative interpretations of such marriages were specific features of 18th century London where it was often frowned upon when a cultured man married a gypsy or when a colored man married a white girl.

Defoe presented the life events of the protagonist of his story, Moll, who was born and abandoned in Newgate Prison. She was forced to make her way in life through husband-hunting, adultery and bigamy. Her desire for a solid identity and her egotism are essential, underlying themes that play an important role in the development of the story. In the beginning, Moll was living with a gentlewoman and her family, and one of the brothers won Moll's heart and seduced her into becoming his lover - "He took these freedoms with me ... when this was over he stayed but a little while, but he put almost a handful of gold in my hand ...” (MF, p. 48).

As marriage was the only profitable opportunity for an 18th century woman, Moll "resolved now to be married, or nothing, and to be well married, or not at all" (MF, p. 51). She soon learned that in a city like London, marriages were "the consequences of politick schemes, for forming interests, and carrying on business, and that LOVE had no share, or but very little in the matter" ( $M F$, p. 96). Moll decided to construct her identity through the institution of marriage and in her quest for security in marriage, she encountered many ordeals, and when her beauty could no longer guarantee her a new rich husband, Moll turned to crime.

Moll was born to a lower-class woman who was convicted of felony and transported to the plantations. Left with Egyptian gypsies, the magistrates of Colchester placed her in the care of an old woman, but after her tragic death Moll spent her adolescence with upper-class families. This transformed Moll into a character of lower-class mentality with upper-class fancies, and she was often torn between her personal aspirations to become a member of gentry and the social realities of living in 18th century London.

Moll had a divided life and the first part of the novel contains her sex adventures, the second portrays her life as a bandit, the third covers her imprisonment and the fourth, her move to the USA. Although married, Moll continued to sell her body for profit - "I found presently that 
whether I was a whore or a wife, I was to pass for a whore here ...” (MF, p. 146). The division in Moll's personality caused her to some extent to live a very confounded life, particularly when love and money were involved. Moll's life was essentially a continual search for an acceptable personal, as well as social, identity.

\section{Explicit Metatextual Elements (Interpretations and Negations)}

Defoe's first strategy for negative interpretation of hybrid marriages was to nominate and refer to the female social actors in Moll's society as economic goods in the marketplace. In applying this, he presented Moll's dilemma as a representative of her kind. For example, in Colchester, Moll lived with a rich family where two brothers and two sisters argued about what had more importance in a marriage: beauty or money. The younger brother, Robin, argued that for a girl to get a good husband, she should be beautiful. In contrast, his sister, being plain, replied that she had money to compensate for her lack of beauty and that her money would surely win her a good husband in the marriage market.

As for Moll who was listening attentively, the more important lesson was that a girl could use her beauty or money to secure a good, if not the best, marriage deal. Ironically, when Robin's elder brother was attracted to her beauty, she failed to engage this and accommodated him without securing anything close to a respectable deal. Later, money became everything for her.

The second strategy for negative interpretation takes the form of explicit judgments about hybrid marriages, with nominal or verbal clauses like "he/she is hopeless with no money" (MF, p. 104), "he/she doesn't care about me" (MF, p. 129), "that man/woman does not suit you or is not for you" (MF, p. 179), and "I/you can never take her for a wife/a husband" (MF, p. 213).

Lastly, there is the portrayal of women having lost the privilege of refusing men, specifically within the context of sexual relationships. Many examples in Defoe's work point to this, for instance: "Do you think [Mrs. Betty] has learnt to say NO, any more than other People?" (MF, p. 50). The phrase "other People" refers to other women of that era. Moll never learnt, or was never able, to deny men or their sexual needs. In a complicated relationship involving two brothers, Moll's initial motivation for rejecting them was her personal interest to gain more money and not her high morals, but she soon discovered that she did not have the power to control both men anyway, in a society largely ruled by men. This recurring theme of dominance, as well as Moll's personal agendas, led to dire problems in her marriages. Also, it can be argued that her loose behavior as portrayed in the novel does cast an unfavorable light on hybrid marriages, as if women of such character are common in such marriages or relationships.

In sum, one could also suggest that Defoe used Moll's marriages as a tool to criticize the rigid male-dominated social structures of 18th century England. He employed these marriages as a means of portraying how much control men of that society could have over women, even the more privileged ones.

\section{Implicit Metatextual Elements (Ironies and Parodies)}

Defoe employed the use of ironies and parodies in his work and one gets the impression of Moll Flanders as a woman of wiles and whims, able to imitate the ladies of the upper class especially in expressing moral issues about marriage and children - and at the same time commit 
lower-class acts such as whoring and thieving. Moll also seemed able to legitimize and justify these acts by exploiting her mastery of upper-class language. In the novel, she basically employed whatsoever mental models available to justify her problematic marriages, her abandonment of her children, and her crimes. For example, there were instances when Moll showed her refrain from and hostility towards men by employing stiff upper-class language, but simultaneously she exposed, via her contrastive (and suggestive) actions, the effects and connotations of her lower-class origins.

All these elements are framed within the macro topic of her hybrid marriages or more specifically, a woman who moved from one marriage to another in relatively quick succession many times to men with backgrounds very diverse to hers - thus permitting readers to take the position of negativity towards social hybridity.

Moll also often resorted to crude measures to ensure her own survival and to attain more wealth. Pregnant and alone, she sought security in the form of marriage to a banker. The irony here, however, is that in order to enjoy security and to preserve her own life, she had to end her child's. She also justified her choice by claiming an upper-class societal standard - the need for her to be in a moral union with a respectable man. This is, again, another form of irony disregarding life and creation to claim morality and attain respectability. Another example of irony was when Moll was finally happily married to a very wealthy man, she discovered (when she went to live with him in Virginia) a biological connection. She discovered that her motherin-law was her own mother and thus her husband was her brother.

Similarly, in another instance, Moll allowed herself to be tempted by a drunk gentleman and when he fell asleep, she stole his valuables. Again, she justified the act by preaching against the man. She claimed that "such a man is worse than a lunatic; prompted by his vicious, corrupted head, he no more knows what he is doing” (MF, p. 248), and cleared herself of all wrongdoing, stressing that justice was needed. She also emphasized that she wanted to prevent the man from "thereby sowing the contagion in the life-blood of his posterity" (MF, p. 249).

The parody strategy is also relatively evident in the novel. Moll is always portrayed as a woman who considers her survival in society a must and she rarely wavers from this stand. Upon the surprising discovery that her husband was actually her brother, she did not tell him or leave him for close to three years. Instead, she legitimized her position by referring to him as "my husband, as he thought himself" (MF, p. 97) and "my husband as he really was" (MF, p. 99).

TEXT 2: RAJENDRA'S NO BED OF ROSES: THE ROSE CHAN STORY

\section{Synopsis (Macro Themes)}

As a lawyer, poet and writer, Cecil Rajendra directed his works towards his country's multicultural society, and is known to have helped poorer individuals who needed legal aid. In his novel, No Bed of Roses: The Rose Chan Story, he presented the story of a migrant who became an infamous striptease dancer in the 1950s and 60s in Malaysia.

Rose Chan (Chan Wai Chang) was born in Soochow, China, in 1925 to travelling acrobat parents. Due to a major famine in China in 1931, her parents sent her, only six years old, to Singapore. As she lost all her possessions at sea, she was sent to foster parents in Kuala Lumpur, 
Malaysia. She soon started helping out in the kitchen and waited tables in her adoptive parents' restaurant. During this period, she acquired the skills of cooking and of making money. She was enrolled in school for the first time in 1937 at the age of 12, but was expelled for tardiness and for selling photos to her friends. After that, she began working in a home-based business making mosquito repellent coils. She was poorly paid. She said: "No one will know how difficult and bitter my life has been. Everyone thinks being a star is so glamorous. They see the glamour but can never share my sorrows and sufferings. No one will ever understand." (RCH, p. 64).

At the age of 16, her first marriage was arranged for her through her adoptive mother in Singapore, to a rich harbor master, Ah Peh. Peh was an old man with four wives to support and a girlfriend. The explicit justification for such an early marriage was to protect her from ending up as a Japanese comfort woman, but implicitly it was because of her adoptive mother's greed for money. Peh, however, soon rejected her and in retaliation, she started working as a cabaret dancer. It did not take her very long to become Malaysia's Queen of Striptease. Her acts included wrestling with pythons, bending iron bars, and having motorcycles ride over her body.

In 1957, she married Indonesian Nazier Kahar, embraced Islam and took the name Rosminah binti Abdullah. She eventually divorced Nazier because:

"Afternoon, if I got home after matinee, he also wan. Rose so tired but he okay mah ... he eat, sleep, smoke cigalette, link kopi, read paper, gonchang kaki (shake leg) at home, but Rose got to work on leg mah ... dance, serve customer, do show, how to rahan (stand)? Worse sum more, I tell you." (RCH, p. 90)

She then met her third husband, Chong Yew Meng, who was a company manager. During her marriage, she continued to perform to a huge audience. In 1965, she married musician Jimmy Chew. Not long after, she was invited to perform in Australia but the authorities stopped her show and she was charged with offensive behavior in a public place.

After divorcing Chew, she opened a restaurant in Malaysia and was actively involved in raising funds for various charities. In 1980, Rose was diagnosed with breast cancer and given six to 18 months to live. Her fifth marriage was to Low Kim Seng. Rose died in 1987 at the age of 62 in Penang.

\section{Explicit Metatextual Elements (Interpretations and Negations)}

In No Bed of Roses, Rajendra concentrated on Rose's fight against poverty, prejudice, hypocrisy and racism which were common ailments of her society then. He accorded much focus to gender distinction and male hegemony, and appears to employ more negative interpretations than positive ones; Rose demonstrated continuous emotional disengagement and withdrawal from her male-driven chauvinistic society, and refused to fully accept the influence of any of her five husbands. Indeed, throughout her five marriages, she was never dependent on her husbands and even labeled three of them as financial parasites.

All her multiracial marriages bear the continuity of her materialistic identities, which evolved according to her experience of localization in Malaysia. Some of her unions became so culturally localized that they demanded a new (hybrid) identity - Chinese-Malaysian. By 'localization', we 
mean the process of becoming a local citizen via social hybridity, which includes making cultural adjustments to one's new, local social environment and identifying with the locality. Cultural adaptation is fundamentally a perpetual process, albeit one that becomes easier with time, and is ultimately much more an active process than a passive one.

Also, in the novel, Rose was generally not particular about the type of husbands she got. She was not concerned about their cultural or social backgrounds, but would later face issues relating to culture shock and religious practices. Rajendra wrote: "Rose was determined to prove to the world that she was not Chinese, Cantonese, Hakka or Hokkien but "one hunnert per sen" Malayan." (RCH, p. 210)

As in Moll Flanders, the vital themes in Rose Chan are identity construction, egotism and vanity, all of which represent the integral components of her character. In fact, most of Rose's actions in the story were almost always a result of her longing for an identity. She was also easily tempted or seduced; she thought any man could fall in love with her because she was, in her own view, very beautiful. In her search for an identity, coupled with her egotism and vanity, we witness a chronicle of unfortunate events pertaining to her love life - "First husband send back to Mama ... kick me out ... then boyfriend cheat me with my sister ... later this fellow Nazier come, bring Rose chocolate, flower and present, say he lup me ... want to marry ... " (RCH, p. $85)$. Nazier turned out to be a financial parasite, and the marriage lasted only three years and bore no offspring.

In her five relationships, the ratio of negative to positive expressions in describing her connection with her partners (often rife with problems and headed towards divorce) is, more often than not, higher on the negative side. In essence, Rose presented as a fact that to have her kind of relationships/marriages without negative effects is impossible. The following extracts are examples:

"Rose fed up men ... cannot trust one ... first husband send me back to Mama ... kick me out, chase other women ... then boyfriend cheat me with my sister, so how to trust men, you tell me?" $(\mathrm{RCH}$, p. 87)

"When Rose go to work, my chelaka itek (bastard duck) go out look for kampong chicken! He tink I so stoopid, I doan know! One day I come back early, I catch his backside on top of kampong chicken. I one shot kick him out!" (RCH, p. 94)

\section{Implicit Metatextual Elements (Ironies and Parodies)}

No Bed of Roses is one of the more heartrending tragedies in Malaysian literature, and Rajendra's use of situational and dramatic irony is one of the reasons why the novel is so powerful. Broadly, the view portrayed is that although hybrid marriages, and the children produced from these unions, can be rays of hope for racial/ethnic integration, peace and harmony, all Rose received from her relationships were mostly emotional distress and further withdrawal from her society. 
Secondly, the irony of Rose's life; the end result of her life in Malaysia was vastly different from what she had expected it to be. She basically escaped famine for infamy, aside from the ordeals of her marriages. Also, linguistically, a number of the expressions employed in the novel are observed to be ironically varied but aptly used to describe her struggles and the pain and loneliness that she must have felt. For instance, expressions like 'sale' and 'transaction' instead of 'marriage':

"The marriage would not only make 'Mama' look good in the eyes of the Chinese community but enrich her coffers as well. But 'sale' not 'marriage' would be a more apt description of the transaction. Ah Chan was sold for \$3,000, a pair of diamond earrings, a gold chain, a gold bracelet and a jade locket." (RCH, p. 114)

In addition, parodies were also utilized to describe situations in which his heroine went against the authorities of her time. For example:

" Rose was also aware that some quarters had accused her of making a living out of 'indecency' and gone as far as to brand her 'a corrupter of morals'. To which Rose's succinct retort was "I doan gip a fug". " (RCH, p. 211)

\section{CONCLUSION}

Social hybridity or hybrid socialization affects the way in which real individuals or fictional characters find or develop a particular multiracial identity that is meaningful to them. In our research on Defoe's Moll Flanders and Rajendra's No Bed of Roses, we found it useful to analyze the two heroines' search for an identity within the terms of social hybridity. Namely, the experience of identification via multiple unions and the objective expression of a largely materialist identity. In both cases, the language of business is crucial to the understanding of the objective expressions, and even the adoption of specific expressions of identity, such as the use of certain slangs or language related to sex.

Having concluded the metatextual analysis for both novels, there appears to be a level of similarity between them. On the whole, both texts comment on issues pertaining to hybrid marriages, especially the negative dimensions. The two authors have drawn our attention to heroines with lives reformatted for specific purposes (money, sex, fame and survival) and due to specific reasons (poverty, prejudice, rigid norms, male dominance and parasitic men).

With No Bed of Roses, Rajendra fundamentally wrote his text as a story that does not break from reality. Defoe placed clear boundaries between both worlds in his narrative (e.g., via parodies) and seems to have done too much of what Moll Flanders was supposed to do. As for No Bed of Roses, it reminds us of facts along the story and Rajendra did interrupt the stream of the story quite substantially in order to pull it together. 
Defoe's Moll Flanders emphasized the refusal to take for granted how a life story should be told and thus he often implicitly commented on the nature of his heroine's life from a unique perspective, and attempted different possibilities for his heroine's story. He also punished Moll for her hybrid marriages, emphasized her whoredom, her illegal acts, her greed, and her wickedness. Rajendra, on the other hand, appears to tolerate better his heroine, and guided us to Rose's recovery and redemption after her five marriages.

In No Bed of Roses, there was a lot of what could perhaps be called 'the language of business', utilized to link her matrimonial unions with conducting business. Her decisions to become a wife always rose from her realization that marriage was a new business in a capitalist society. Many times she used informal language or expressions to communicate with her friends and family regarding this. Similarly, Moll also used 'the language of commodities' to describe her marriages. Yet her language was more often than not a mixture of both the upper and lower social classes. Still, marriage for her is a "market" (MF, p. 254) in a "stock" $(M F$, p. 225) of beauty and cash.

In sum, both heroines were evidently fond of amassing money and possessions. Interestingly, Moll appeared to suffer from a more compulsive need to amass greater wealth than Rose. This might be due to Moll's early years as an orphan living in severe poverty. Conversely, Rose seemed to care more about profiting from her society (like Moll, in questionable ways and throughout most of her multiple marriages) for a better future and much later on in life, for the welfare of the less fortunate in her society. On the whole, it appears that there are clear instances of the shaping of disinclination for hybrid marriages and their resultant social identities, with Defoe's work exhibiting more of such instances than Rajendra's.

This study and its findings are of relevance and importance to scholars engaged in literary research. Additionally, they are of significance in terms of promoting students' critical and creative thinking, as well as their understanding of Western and Eastern comparative literature, with respect to identity construction and mutual communication in varied societies. The symbolism of the characters discussed in the present study also allows for further exploration within the context of interpretative studies, and presents an interesting avenue for educators to delve into with their students.

Within the scope of education, we recommend that future studies extend the present one to cover more literary works and to focus on the relationship between Western and Eastern literature, specifically within the structure of colonial and post-colonial functioning of hybridity, individual variations, and language-specific elements to facilitate and enhance the process of teaching English literature. With regards to scholarly endeavours, since our study has demonstrated that more than one intertextual relation can be found in Western and Eastern literature, we suggest that researchers investigate other literary productions in efforts to identify similar relationships and correlations to further enrich the existing knowledge base that we have today. 


\section{REFERENCES}

Allen, G. (2000). Intertextuality. London: Routledge. https://doi.org/10.4324/9780203131039

Barthes, R. (1974). S/Z: An Essay (R. Miller Trans.). New York: Hill \& Wang. Retrieved: http://bookzz.org/

Bell, R. (1993). Translation and Translating: Theory and Practice. London/New York: Longman.

Bloor M., \& Bloor, T. (2007). The Practice of Critical Discourse Analysis: An Introduction. London: Hodder Arnold Education.

Defoe, D. (1996). The Fortunes and Misfortunes of the Famous Moll Flanders. David Lascelles (Ed.). London: Penguin.

Fairclough, N. (1999). Linguistic and Intertextual Analysis within Discourse Analysis. In N. Jaworski \& N. Coupland (Eds.). The Discourse Reader (pp. 183-211). London/New York: Routledge.

Fairclough, N. (2003). Analysing Discourse: Textual Analysis for Social Research. London/New York: Routledge. https://doi.org/10.4324/9780203697078

García-Canclini, N. (2001). Hybridity. In N.J. Smelser \& P.B. Baltes (Eds.). International Encyclopedia of the Social and Behavioral Sciences (pp. 7095-7098). Oxford: Elsevier. https://doi.org/10.1016/B0-08-043076-7/00890-1

Genette, G. (1992). The Architect: An Introduction (J.E. Lewin Trans.). Berkeley: University of California Press.

Genette, G. (1997). Paratexts: Thresholds of Interpretation (J.E. Lewin Trans.). Lincoln, NE/London University: University of Nebraska Press.

Halliday, M. (2002). On Texts and Discourse (Vol. 2). London/New York: Continuum.

Halliday, M. (2003). On Language and Linguistics (Vol. 3). London/New York: Continuum.

Kristeva, J. (1980). Desire in Language: A Semiotic Approach to Literature and Art. Columbia University Press. Retrieved: http://bookzz.org/

Kristeva, J. (1986). The Kristeva Reader. Oxford: Basil Blackwell.

Little, K. (2002). Negroes in Britain: A Study of Racial Relations in English Society. London: Routledge.

Marotta, V.P. (2008). The Hybrid Self and the Ambivalence of Boundaries. Social Identities, 14(3), 295-312. https://doi.org/10.1080/13504630802088052

Mollanazar, H., \& Parham, F. (2009). Trends in and Manifestations of Hybridity. Translation Studies, 7(27), 29-48.

Porter, R. (1991). English Society in the Eighteenth Century. London: Penguin.

Rajendra, C. (2013). No Bed of Roses: The Rose Chan Story. Singapore: Marshall Cavendish International (Asia).

\section{Authors:}

Ali Badeen Mohammed Al-Rikaby (Dr.) is a lecturer and researcher attached to the College of Arts in Mustansiriyah University, Iraq. He previously served as Assistant Director of the Studies Abroad Section (Iraqi MOHSR), Head of the Translation Centre of Mustansiriyah University, 
and Head of the English Language Department at Libya's College of Education. His research interests include language and literature studies, as well as translation and discourse analysis.

Siham Hattab Hamdan (Dr.) is a graduate of the College of Arts, Mustansiriyah University (Baghdad, Iraq). She is currently an instructor in the Department of English Language and Literature in the university. Her areas of specialization include the study of travel in literature and the study of sociopolitical dimensions in contemporary novels. She has published widely in these areas.

Tengku Sepora Tengku Mahadi (Professor Dr.) is attached to the School of Languages, Literacies and Translation, Universiti Sains Malaysia. Her experience is extensive, both in administrative and academic capacities. She has published widely with many journal articles and books to her name. Her research interests include philology, sociolinguistics, translation studies, and discourse analysis.

Debbita Tan Ai Lin (Dr.) serves as Senior Lecturer at the School of Languages, Literacies and Translation, Universiti Sains Malaysia. She is keen on interdisciplinary research and her areas of interest include language and media/political studies, applied linguistics, and discourse analysis.

Shaidatul Akma Adi Kasuma (Dr.) is Senior Lecturer at the School of Languages, Literacies and Translation, Universiti Sains Malaysia. She is academically interested in diverse areas of English language studies including TESL, technology in language learning, applied linguistics, sociolinguistics, discourse analysis, teaching methodology, autonomous learning, and higher education. 